\title{
HAEMOLYTIC MECHANISMS IN HEALTH AND DISEASE*
}

BY

\author{
J. V. DACIE, M.D., F.R.C.P. \\ Postgraduate Medical School of London
}

I am conscious of the honour done to me on being appointed Oliver-Sharpey Lecturer for 1962, and I trust that consideration of the factors which limit the life of the red blood cell in health and which shorten its lifespan in disease will be thought to be subjects worthy of being ranged alongside the topics chosen by many eminent predecessors who have held this lectureship, the object of which is " to promote physiological research by observation and experiment, and to encourage the application of physiological knowledge to the prevention and cure of disease and the prolongation of life."

Knowledge of the mechanism of anaemia has increased very greatly in the last two decades, and this is certainly true of the large group of blood disorders, the haemolytic anaemias, which are characterized by a reduction in the life-span of the red blood cells. Parallel with the increase in understanding of haemolytic mechanisms has been a remarkable increase in know'ledge of the nature of the red cell itself. This cell, at one time generally looked upon as being not much more than an inert bag of haemoglobin, now is known to have a complex metabolism, a highly organized although still controversial surface ultrastructure, and a finite life-span. In health, the red cell's life-span, 100-120 days, is relatively constant; but in disease it may be shortened to one-tenth of the normal, or even less.

In this lecture on haemolysis in health and disease I shall not deal with the techniques that have been used for measurement of red-cell life-span, but rather with the factors which limit the life of the normal red cell to a fairly closely defined period and with the various mechanisms which shorten the cells' life-span in disease. I shall also refer to the site or sites of haemolysis.

The subject and scope of this lecture is almost the same as that of Peyton Rous's (1923) classic review. Many of the mechanisms and problems of hasmolysis that I shall discuss were also discussed by Rous, and if I can carry the subject a little further than he did I have the advantage of almost 40 years of hind-sight.

\section{HAEMOLYSIS IN HEALTH}

Recognition of the origin of bile pigment from haemoglobin and that injection of haemoglobin leads to increased excretion of bile pigment dates back to the nineteenth century (see Rous, 1923). But, inevitably', little was known of the mechanisms involved in the dayto-day breaking down of the red cells. Rous's (1923) review nevertheless reveals the interest which physiologists, pathologists, and physicians from many countries

*Oliver-Sharpey Lecture given at the Royal College of Physicians of London on March 5, 1962. of the world had taken in the problem. Erythrophagocytosis, fragmentation of red cells, and the effect of naturally occurring haemolysins were all discussed as possible mechanisms, but the evidence in favour of any particular mechanism operating in health was not substantial. Rous, referring to phagocytosis and fragmentation, concluded: "The amount of phagocytosis normally going on in the body is often insufficient to account for the disappearance of many cells whereas a constant slight fragmentation throughout the circulation will readily do so." He added, however, that both processes might be of little consequence compared with some other, as yet unrecognized, mechanism.

Little progress was made in the succeeding decade. This is illustrated by Isaacs (1937), who stated: "We are still unable to say how aged red blood cells are normally disposed of, or even the exact place. Phagocytosis, fragmentation, and haemolysis occupy the same relative importance to-day that they did when Rous compiled his review in 1923." This is not to say that a great deal of experimental work had not been done, mostly before 1920 , on animals which were injected with haemotoxic drugs or haemolytic immune sera. The difficulty was, and still is to some extent, the relevance to the healthy man of observations made on experimental haemolytic anaemia in animals. However, Rous and Robertson (1917) sought for, and found some evidence of, red-cell fragmentation in healthy animals, and also in man, and concluded that fragmentation was an important mechanism and phagocytosis a secondary one. But how and why the fragmentation occurred remained a mystery.

\section{Recent Studies}

I shall now turn to more recent studies, made possible by the rapid evolution of biochemical methods and to some extent also by the introduction of isotope labelling techniques. These studies have centred around the demonstration of differences between young and old red cells: differences in chemical composition, in synthetic capabilities, in sensitivity to various in vitro tests, and possibly, too, in morphology. The use of the radioactive isotope of iron, ${ }^{: 9} \mathrm{Fe}$, has enabled red-cell populations to be labelled according to their age and has shown that the red cells of whole blood can be separated by differential centrifugation into a less dense (predominantly young) population and a more dense (predominantly old) population (Borun, Figueroa, and Perry, 1957 ; Prankerd, 1958 ; Jandl, 1961).

It is now known that while the content of haemoglobin and stromal proteins remains probably the same throughout a cell's life a certain amount of lipid may 
be lost (Prankerd, 1958), and the concentration or activity of certain enzymes can be shown to diminishfor example, cholinesterase and catalase, glucose-6phosphate dehydrogenase, 6-phosphogluconic dehydrogenase, phosphohexose isomerase, aldolase, and phosphoglyceraldehyde dehydrogenase (Allison and Burn, 1955; Marks and Johnson, 1958; Marks, Johnson, Hirschberg, and Banks, 1958: Löhr, Waller. Karges, Schlegel, and Müller, 1958 ; Bernstein, 1959). Bernstein (1959) also found that the rate of glycolysis was less in the older cells, that there was a lower high-energy phosphate-ester content, that cation-steady states were at a lower level of active transport, and that if an old-cell population was refrigerated there was a greater loss of potassium. These and other studies have led to a concept of ageing of the red cell accompanied by a gradual diminution in its metabolic capabilities, the ageing process being probabiy mainly due to a progressive loss of enzymes which cannot be replaced and a failure to phosphorylate adenosine diphosphate to adenosine triphosphate, a key substance in the cells' metabolism (London, 1960 : de Gruchy, 1960 : Marks, 1961).

The other abnormalities which have been cetected in older cell populations, such as increase in density, in osmotic fragility (Simon and Toppar, 1957 ; Prankerd, 1958; Marks and Johnson, 1958), and in mechanical fragility (Stewart, Stewart, Izzo, and Young, 1950) are all probably secondary to the metabolic changes. This is presumably also true of the stibtle surface changes which can be demonstrated by electron microscopy. According to Danon and Marikovsky (1961) young cells have a surface structure which is less smooth and regular than that of older " mature" cells.

It has often been stated that normal red cells alter in shape as they mature (Dameshek and Schwartz, 1959). There is, it is true, ample evidence that reticulocytes are normally larger in diameter and thinner than mature red cells, but whether mature cells become still more spheroidal as time passes is not so certain. They may well do so. In vitro, stored red cells eventually lose their normal disk-like shape, and in vivo increased spherocytosis is an important consequence of the relatively prolonged stagnation of blood which takes place in the spleen in hereditary spherocytosis. It is thus possible that the relatively short but often repeated passages of normal red cells through the normal spleen lead eventually to a minor degree of spherocytosis.

This tendency of old cells to be more spheroidal than young cells cculd, however, equally well be due to the cells' gradual metabolic failure. There is, moreover, except in the rat (Belcher and Harriss, 1959), no evidence that splenectomy carried out on a healthy animal is associated with any substantial increase in longevity of the red cells (Singer and Weisz, 1945, in dogs: Miescher. 1956, in rabbits). In man, evidence on the effect of splenectomy on the life-span of normal red cells is insufficient to draw any conclusions, but it seems unlikeiy that temporary sequestration of normal red cells within the pulp of a normal spleen centributes significantly to the cells' eventual metabolic failure. The spleen in health in man does not in fact seem to play an important part in physiological haemolysis.

There is now little doubt that the changes of ageing are responsible for the eventual destruction of the normal red cell, but it is not yet clear whether the effete red cell is removed from the blood-stream in one piece or undergoes fragmentation first, either as the result of a final intrinsic failure of the cell's structure or to loss of flexibility of the cell resulting in a break-up due to mechanical stresses when circulating through capillaries or as a rather special case when being squeezed through the stomata in the walls of the splenic sinuses (see TeitelBernard, 1930 ; Weiss, 1957).

As Rous and Robertson (1917) pointed out, fragments of red cells (schistocytes) are difficult to see in circulating blood in health in man. This could, however, be due to the rapidity with which effete red cells or their fragments leave or are filtered off from the circulation. In all probability they are engulfed by phagocytic cells to which it can only be presumed that they adhere by virtue of some alteration to their surface.

Where effete red cells or their fragments are removed from the circulation is not known for certainty in man. Probably this occurs whenever red cells come in contact with potentially phagocytic reticulo-endothelial cells, in the liver, therefore, and in the spleen and bone-marrow and in lymph nodes, too. In animals this has been put to the test using isotopically labelled red cells. There seem to be species differences: in rabbits the bonemarrow is probably the most important site (Miescher, 1956 ; Hughes Jones, 1961); in the rat this appears to be the spleen (Hughes Jones and Cheney, 1961). In man the relative importance of the various reticuloendothelial organs is not known.

\section{HAEMOLYSIS IN DISEASE}

In disease a surprising number of different abnormalities or mechanisms lead to shortening of red-cell lifespan. These abnormalities and haemoiytic mechanisms are of two main kinds: (1) abnormalities of the red cells themselves ("intrinsic" defects), often genetically determined, and (2) acquired abnormalities, not primarily of the red cells. It will be convenient if each main group is dealt with separately.

Before, however, dealing with the mechanisms of haemolysis in particular diseases it is necessary to discuss very briefly the terms "intravascular" and "extravascular" haemolysis. The use of these terms or their equivalents dates back to the first decade of the present century. Hunter (1901), for instance, distinguished between "acute haer:ocytolysis" where there is a "liberation of haemoglobin from the corpuscle" and " chronic haemocytolysis" where the red cells " continue to circulate until finally they are enclosed within the active cells of the spleen." The concept of intravascular and extravascular haemolysis still stands to-day, but it is realized that the difference between the two can be explained more often than not on a quantitative basis ; that is to say, severe damage to red cells, by a variety of mechanisms, will lead to lysis in the blood-stream, while a lesser degree of damage of the same type will lead predominantly to removal of the damaged cells from the blood-stream by organs rich in phagocytic reticulo-endothelial cells, such as the liver, spleen, and bone-marrow. This is. however, not to say that in some exceptional instances-for example, in paroxysmal nocturnal haemoglobinuria-destruction is not always predominantly intravascular, even in the mildest cases of the disease.

\section{Haemolytic Anaemias Caused by Abnormalities of Red Cells : I, Inherited Types}

The main hereditary and congenital haemolytic anaemias are listed in Table $\mathrm{I}$. 
TABle I-Haemolytic Anaemias Caused by Abnormalities of Red Cells (Intrinsic Defects): I, Inherited Types

Hereditary haemolytic anciemius Hereditary sphercecytosis$$
\text { " elliptocytosis }
$$

T̈ype I and Type II

Other types

The haemoglobinopathies

$\mathrm{Hb}-\mathrm{S}$ disease, $\mathrm{Hb}-\mathrm{C}$ disease, $\mathrm{Hb}-\mathrm{D}$ disease, $\mathrm{Hb}-\mathrm{S} / \mathrm{Hb}-\mathrm{C}$ disease, et Mediterranean anaemia (thalassaemia major and minor) $\mathbf{H b}-\mathrm{S}$ thalassaemia; $\mathrm{Hb}-\mathrm{H}$ thalassaemia, etc. Congenital Heinz-body anaemia

Giucose-6-phosphate dehydrogenase deficiency Drug sensitivity haemolytic anaemias Favism

\section{Hereditary Haemolytic Anaemias}

Diverse biochemical abnormalities lie at the root of each type of disorder, and the probability is that morphological abnormalities where present are secondary to metabolic deficiencies. This is a rapidly growing subject, and it is not possible to do more than mention some of the more interesting of recent developments.

\section{Hereditary Spherocvtosis}

It has proved difficult to define the exact abnormality of the hereditary spherocytosis red cell, and it is uncertain whether the primary abnormality is a fault in the energy-providing glycolytic mechanism or in phospholipid metabolism. There is some evidence that the cells lack the ability to phosphorylate adequately certain phosphate esters (Prankerd, Altman, and Young, 1955), but which enzyme or enzymes are at fault is uncertain ; possibly enolase (Tabechian, Altman, and Young, 1956 ; Prankerd, 1959) or phosphofructokinase (Prankerd, 1959) is involved. On the other hand, on incubation hereditary spherocytosis red cells lose more lipid than do normal cells (Prankerd, 1960; Reed and Swisher, 1960), and Reed and Swisher concluded that the cells were unable to maintain the integrity of the structural lipids of their surface because of inefficient energy production. More recently, however, Kates, Allison, and James (1961), finding in two cases a relatively high proportion of lysophosphatidyl ethanolamine, have suggested that the primary genetically controlled abnormality in hereditary spherocytosis is a block in the enzyme system required for the conversion of lysophosphatidyl ethanolamine to phosphatidyl ethanolamine and that the spherocytosis and the abnormalities in glycolysis are all secondary to the abnormality in phosphatide metabolism. In this respect it is interesting to note that hereditary spherocytosis is distinguished from the other hereditary haemolytic anaemias by the characteristic abnormality of the cells' phospholipidcontaining surface-namely, the sphərocytosis.

Even if the abnormality of the hereditary spherocytosis cell is somewhat uncertain, there is no doubt that the greater part of the excess haemolysis takes place within the spleen and that the biochemical abnormality is of a type which makes the cell peculiarly sensitive to the effects of stasis in the labyrinth of the spleen. There is some reason to believe that it is glucose deprivation resulting from the stasis which leads to the ultimate lysis of the stagnant blood (Selwyn and Dacie, 1954 ; Jandl, Simmons, and Castle, 1961). Whether or not it is the spherocytosis per se which leads to the sequestering of the red cells in the spleen is still uncertain, but the probability is that the shape-change plays at least a part in this (Jandl et al., 1961).

\section{Hereditary Elliptocytosis}

The red cells in hereditary elliptocytosis are not only abnormal in shape but are probably metabolically abnormal also (de Gruchy, Loder, and Hennessy, 1962), and, as in hereditary spherocytosis, a significant degree of splenic sequestration can be demonstrated if the patient's red cells are labelled with radioactive chromium. It is, however, not known as yet whether it is shape per se or more subtle surface abnormalities which lead to the retention of the red cells by the spleen. The latter appears to be more likely, as the degree of morphological abnormality is not paralleled strictly by the severity of in vivo haemolysis.

\section{Hereditary Non-spherocytic Haemolytic Anaemias}

These are a group of disorders which are clearly separable from hereditary spherocytosis. Clinically, as opposed to hereditary spherocytosis and hereditary elliptocytosis, they differ in that splenectomy is of little or no value in controlling the haemolysis, and there are also major haematological differences. The underlying biochemical abnormalities have not as yet been fully worked out, but there is reason to believe that they are quite distinct from those of hereditary spherocytosis.

Two types of non-spherocytic haemolytic anaemia were originally distinguished by Selwyn and Dacie (1954) on the basis of red-cell morphology, the effect of incubation on osmotic fragility, the rate of spontaneous lysis of sterile incubated blood, and the effect thereon of the addition of glucose (Table II).

TABLE II.-Morphological and Other Differences Betwieen the Red Cells in Hereditary Non-spherocytic Haemolytic Anaemia

\begin{tabular}{|c|c|c|c|}
\hline Type & $\begin{array}{l}\text { Red } \\
\text { Cells }\end{array}$ & $\begin{array}{l}\text { Osmotic Fragility } \\
\text { (Fresh Blood and } \\
\text { after } 24 \text { Hours' } \\
\text { Incubation) }\end{array}$ & $\begin{array}{c}\text { Autohaemolysis } \\
\left(48 \text { Hours at } 37^{\circ} \mathrm{C} .\right)\end{array}$ \\
\hline $\mathbf{I}$ & $\begin{array}{l}\text { Round, oval, or } \\
\text { sligatly elliptic } \\
\text { macrocytes }\end{array}$ & $\begin{array}{l}\text { Normal before incu- } \\
\text { bation: may be } \\
\text { slightly abnormal } \\
\text { after }\end{array}$ & $\begin{array}{l}\text { Normal or slightly } \\
\text { increased: usually } \\
\text { diminished by less } \\
\text { than normalamount }\end{array}$ \\
\hline II & Round macrocytes & $\begin{array}{l}\text { Normal, before incu- } \\
\text { bation: greatly in- } \\
\text { creased after }\end{array}$ & $\begin{array}{l}\text { Greatly increased; } \\
\text { not diminished by } \\
\text { glucoss }\end{array}$ \\
\hline
\end{tabular}

Robinson, Loder, and de Gruchy (1961) provided evidence of impairment of adenosine triphosphate production in the red cells in both types of case, but they concluded that the metabolic block was probably different in type I and type II cases. Prankerd (1961) suggested that one group of patients might have a defect in diphosphoglyceromutase activity. More recently, Valentine, Tanaka, and Miwa (1961) have identified the enzyme which is deficient in type II cases as pyruvate kinase. Moreover, they were able to show by extensive family studies that the type II disease is based on the inheritance of a recessive gene and that heterozygotes, although healthy, can be readily distinguished by their red cells having about one-half the normai pyruvatekinase activity.

It had been suspected for some time that type I hereditary non-spherocytic haemolytic anaemia might comprise more than one disorder. Now it is known that in a minority of cases gross deficiency of the enzyme glucose-6-phosphate dehydrogenase may be demonstrated (Shahidi and Diamond, 1959; Kirkman and Riley, 1961). The nature of the defect or defects in the majority of type I cases remains to be determined, but no doubt this will be accomplished soon. 
The mechanism of haemolysis in all these types of non-spherocytic haemolytic anaemia is not known with certainty. It is clear, however, that the nature of the defect does not cause the cells to be filtered off from the circulation predominantly in the spleen. Taking the group of non-spherocytic haemolytic anaemias as a whole, the probability is that the metabolic defects in the red cells lead to changes which are equivalent to those of physiological ageing occurring at a greatly accelerated rate and that the effete cells or their frag. ments are removed from the circulation by phagocytic reticulo-endothelial cells throughout the body. Hence the clinical ineffectiveness of splenectomy.

\section{The Haemoglobinopathies}

Haemolysis is most striking where $\mathrm{Hb} \mathrm{S}$ is present either in homozygous form or in combination with thalassaemia or $\mathrm{Hb} \mathrm{C}$ or $\mathrm{Hb} \mathrm{D}$, and lesser degrees of haemolysis are found where $\mathrm{Hb} \mathrm{C}$ or $\mathrm{Hb} \mathrm{D}$ is present in homozygous form or when $\mathrm{Hb} \mathrm{H}$ is combined with thalassaemia. Haemolysis seems to occur secondarily to impaction of sickled red cells in capillaries, particularly in organs where the oxygen tension is low, and perhaps also to the rigidity of sickled cells leading to their fragmentation by the normal stresses of the circulation, or by the sickling interfering in some way with normal metabolic processes.

How and why the presence of abnormal haemoglobins such as $\mathrm{Hb} \mathrm{C}$ or $\mathrm{Hb} \mathrm{E}$ causes excessive haemolysis is not clearly understood. Their presence affects the shape of the red cells, as is shown by target-cell formation, but possibly, too, the normal flexibitity of the cells is impaired. In homozygous $\mathrm{Hb} \mathrm{C}$ disease it is possible that intracellular haemoglobin crystal formation may be important (Smith and Krevans, 1959) and that the rigidity of the cells containing rod-shaped crystals may lead to their retention within the spleen.

In Hb H/thalassaemia Rigas and Koler (1961) have suggested that there are two mechanisms leading to haemolysis: first, that the susceptibility of $\mathrm{Hb} \mathbf{H}$ to denaturation leads to the development of insoluble inclusions within the red cells after 40-45 days which in their turn lead to the cells being filtered off from the circulation by the spleen; secondly, that $\mathrm{Hb} \mathbf{H}$ is precipitated in cells irrespective of their age as the result of deoxygenation, and this is thought, too, to lead to the cells' premature destruction.

\section{Congenital Heinz-body Anaemia}

In this rare and recently recognized type of haemolytic anaemia intracellular degradation of haemoglobin to Heinz bodies is associated with a marked shortening of red-cell life-span and the excretion of unusual metabolites of haemoglobin which give rise to darkening of the urine (see Dacie, 1960; Schmid, 1961). The cause of the degradation of haemoglobin is unknown, but Grimes and Meisler (1962) have obtained evidence that the instability of the patient's haemoglobin may be an intrinsic property of the haemoglobin itself rather than the consequence of an enzymic defect of the red cells. Splenectomy is ineffective as treatment, and haemolysis in vivo presumably takes place widely throughout the reticulo-endothelial organs of the body. Haemoglobin is a constituent of the red cells' surface ultrastructure-red-celi " ghosts" contain haemoglobin -and the progressive degradation of haemoglobin presumably leads to an increasing surface abnormality of the red cells, as is shown by the small contracted and crenated cells containing Heinz bodies which may be seen in blood films.

\section{Mediterranean Anaemia}

Haemolysis is often an obvious feature in the homozygous state (thalassaemia major), and it may be found to a lesser degree in some cases of the heterozygous form of the disease (thalassaemia minor). Failure of haemoglobin formation leads to the delivery from the marrow of many bizarre-shaped red cells, and the presence of irregularly shaped microcytes suggests that fragmentation in the blood-stream is an important mechanism of haemolysis. It seems inevitable that as haemoglobin is a normal constituent of the red cell's surface structure a gross deficiency in haemoglobin synthesis will by itself result in the formation of structurally imperfect red cells. This could be an important factor in curtailing the cells' life-span. It is possible, too, that haemoglobin-deficient cells which are imperfect morphologically are also imperfect metabolically.

\section{Glucose-6-phosphate Dehydrogenase Deficiency}

It was the discovery that certain negro subjects developed haemolytic anaemia when taking the antimalarial drug primaquine that led to the recognition that the red cells of a substantial proportion of the negro population and of certain other ethnic groups-for example, Sephardic Jews-are deficient in the enzyme glucose-6-phosphate dehydrogenase (see Beutler, 1959). These enzyme-deficient subjects do not normally suffer from haemolytic anaemia, but many drugs, including primaquine, already mentioned, and phenacetin, sulphanilamide, sulfoxone, thiazosulphone, and sulphacetamide, precipitate haemolytic crises in doses which have no harmful effect on normal subjects. It is now known, too, that favism, the haemolytic anaemia due to ingestion of broad beans, or even to inhalation of broad-bean pollen, occurs only in enzyme-deficient subjects.

It seems likely that the drugs mentioned above exert their harmful effect on the red cells by acting as powerful oxidizing agents and that deficiency of glucose-6phosphate dehydrogenase increases the sensitivity of the red cells to the drugs by impairing the cells' ability to bring about their metabolic degradation. The net result of this is usually fulminating haemolysis occurring in the blood-stream, with spherocytosis and Heinz bodies being obvious if blood is examined early in an attack.

\section{Intrinsic Abnormalities of the Red Cells : II, Acquired Types}

Leaving aside the congenital disorders, there are a number of other types of haemolytic anaemia, of apparently or patently acquired origin, which are associated with red-cell abnormalities that appear to be of the intrinsic type (Table III).

\section{Table 111.-Haemolytic Anaemias Caused by Abnormalities of Red Cells (Intrinsic Defects): 1I, Acquired Types \\ Paroxysmal nocturnal haemoglobinuria \\ Dyshaemopoietic anaemias \\ Vitamin-B 12 $^{2}$ deficiency, leukaemia, aplastic anaemia, etc. \\ Paroxysmal Nocturnal Haemoglobinuria}

P.N.H. is a remarkable disease which is of great interest from both the clinical and the haematological point of view. The probability is that the P.N.H. cell 
has an abnormal surface structure which renders it sensitive to haemolysis by components present in normal plasma-properdin, complement and magnesium ions seem to be particularly important (Hinz, Jordan, and Pillemer, 1956). Possibly because of surface imperfections, the P.N.H. cell adsorbs the potentially lytic properdin-complex abnormally easily while normal cells fail relatively or absolutely to do this (Isliker, 1959). The net result is continuous intravascular haemolysis. The in vitro test for P.N.H. using acidified serum is based on the rather narrow $p \mathrm{H}$ requirement for the haemolytic system, the optimum $p \mathrm{H}$ being about 6.8 .

The exacerbation of haemolysis accompanying sleep, which is a characteristic of the disease, has not yet been satisfactorily explained, and it seems unlikely that it is due to a fall in plasma $p \mathrm{H}$. There must be other more subtle diurnal variations in the haemolytic activity of the plasma, the nature and cause of which can only be guessed at at the present time.

The nature of the P.N.H. cell defect is still unknown. The cells are deficient in acetylcholinesterase (De Sandre, Ghiotto, and Mastella, 1956; Auditore and Hartman, 1959 ; Metz, Bradlow, Lewis, and Dacie, 1960), and they may be abnormal metabolically in other ways (Altman, Tabechian, and Young, 1958), but the significance of these findings has not yet been clarified. Electromicrographs have revealed an unusually patchy appearance of the cells' surface membrane (Matthes, Schubothe, and Lindernann, 1951; Braunsteiner, Gisinger, and Pakesch, 1956 ; Cecchi and Conestabile, 1957).

A remarkable feature of P.N.H. is that not all the patient's cells appear to be defective. In tests in vitro, $80-90 \%$ haemolysis is about the maximum that can be attained (Dacie, 1954a), and in vivo survival studies also have demonstrated the presence of apparently normal cells in untransfused patients (Lewis, Szur, and Dacie, 1960). In some patients, too, only a small proportion of cells may be affected, and sometimes this amounts to less than 10\% (Dacie and Lewis, 1961). Such patients may be clinically healthy or they may be anaemic owing to concomitant marrow hypoplasia. The reason for the presence of only a proportion of abnormal and short-lived cells is unknown, but the phenomenon is an interesting one and invites speculation. A possible hypothesis is that the patient has developed, perhaps as the result of somatic mutation, a clone of abnormal cells which are more or less successful, but never completely successful, in supplanting the normal cell population. The well-known association of the P.N.H. defect with marrow hypoplasia, either of unknown origin or even possibly drug-induced (see Dacie and Lewis, 1961), could be explained on the hypothesis that this type of (?) mutation occurred more frequently in regenerating hypoplastic marrow than in normal bone-marrow.

\section{Other Acquired Intrinsic Red-cell Defects}

An increase in the rate of haemolysis is a common accompaniment of disturbed red-cell formation, be it the result, for instance, of vitamin- $B_{12}$ deficiency or leukaemia (see Dacie, 1954b) or aplastic anaemia (Lewis, 1962). Morphological abnormalities of the red ceils and their precursors are characteristic findings in the three disease groups mentioned. These abnormalities are a reflection of the defective erythropoiesis and the haemolysis is probably at least mainly a consequence of the presence of the morphologically abnormal or biochemically defective cells which are imperfect in one way or another.

The cells from patients with pernicious anaemia, leukaemia, and aplastic anaemia, and some other dyshaemopoietic blood disorders share with P.N.H cells, although to a lesser degree, the property of being unusually easily lysed in vitro by high titre cold agglutinins (Lewis, Dacie, and Tills, 1961). This presumably is a consequence of an abnormal cell surface, but the acidified-serum test is negative in such patients and there is no reason to suppose that the cells' abnormality is the same as the P.N.H. abnormality or that haemolysis in vivo is brought about by the properdin complex.

\section{Haemolytic Anaemias Not Caused Primarily by Abnormalities of Red Cells}

The remainder of the acquired haemolytic anaemias come into this category (Table IV). In each instance the patient's red cells were originally normal, but they often undergo gross morphological changes as the result of the disease process to which they are exposed.

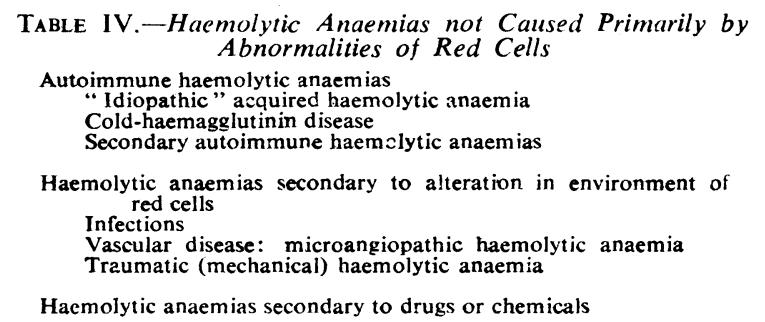

\section{Autoimmune Haemolytic Anaemia}

These are a large group of disorders ; they include so-called "idiopathic" acquired haemolytic anaemia of the auto-antibody type ; the cold-haemagglutinin disease, paroxysmal cold haemoglobinuria ; and secondary autoimmune types, mainly haemolytic anaemias following virus pneumonia or, occasionally, infectious mononucleosis or other infections, haemolytic anaemia accompanying disseminated lupus erythematosus, haemolytic anaemia associated with chronic lymphocytic leukaemia or reticulosarcoma, and certain drug-induced haemolytic anaemias. Characteristically, the patient's red cells are coated with auto-antibody; this gives rise to a positive direct antiglobulin or Coombs test, and it is the presence of the adsorbed antibody on the cells which, through one mechanism or another, leads to curtailment of their life-span.

The auto-antibodies vary in their chemical nature and laboratory characteristics (see Dacie, 1962a). They also vary in the way in which they bring about haemolysis in vivo. The actual mechanisms are probably closely similar to those by means of which iso-antibodies cause the destruction of incompatible red cells (see Mollison, 1959). Briefly, in relation to the autoimmune haemolytic anaemias, it can be said that antibodies which are powerfully lytic in vitro, such as the Donath-Landsteiner antibody of paroxysmal cold haemoglobinuria, cause haemolysis in the circulating blood-stream predominantly by complement lysis - this is also probably true of the rarely-met-with warm haemolysins.

Agglutinating antibodies cause destruction predominantly in the liver, but also in the spleen and bonemarrow, while the sensitization or "coating" of red cells with the common type of incomplete nonagglutinating type of antibody, which usually leads to 
a much weaker type of auto-agglutination in vivo, results in the filtering off of the affected cells predominantly in the spleen (Jandl, Richardson Jones, and Castle, 1957 ; Jandl and Kaplan, 1960). It shoułd be added, however, that these variations in antibody activity are related to quantitative as well as qualitative differences in the antibody, for heavy coating with incomplete antibody may result in a degree of in vivo agglutination sufficient to cause the removal of red cells from the blcod-stream by the liver as well as by the spleen, and probably, too, by other organs, such as the bone-marrow. This could explain the often indifferent result of splenectomy in patients affected with a serious grade of autoimmune haemolytic anaemia (Chertkow and Dacie, 1956).

What exactly happens to red cells after being filtered off from the circulation is not entirely clear, but erythrophagocytosis is undoubtedly an important mechanism for the disposal of antibody-coated cells, particularly of cells coated but not lysed by complement-fixing antibodies (Bonnin and Schwartz, 1954).

Spherocytosis, which occurs to a greater or less extent in most patients with autoimmune haemolytic anaemias, is a change brought about by antibody-coating (Jandl, 1960). But the way the spherocytosis is produced is somewhat of a mystery, and some antibodies produce much more of it than others. It can occur independently of the presence of the spleen. Possibly it is a consequence of impaired metabolism or alteration of the cell surface, secondary to coating of the cells with antibody protein: in any case it may be looked upon as a prehasmolytic change.

A rare variety of autoimmune haemolytic anaemia that has not yet been mentioned is the type associated with hypersensitivity to drugs (see Dacie, 1962b): The first case was described by Harris (1954) in connexion with the antimony-containing drug stibophen (fuadin), but other drugs are known to act in a similar way. It is thought that the patients form an antibody directed against a drüg/red-cell complex, and that it is the interaction of antibody and antigen at the cell surface which leads to intravascular haemolysis of sometimes cątastrophic severity.

Occasionally, too, acute haemolytic anaemia appears to follow an acute viral or bacterial infection. The pathogenesis of such cases is at present obscure, but in some instances at least the mechanism may be analogous to the drug-induced cases-namely, that a soluble bacterial product or virus adsorbed by red cells leads to antigen-antibody interaction at the red-cell surface, with the result that the carrier red cells undergo lysis in the blood-stream.

\section{Haemolytic Anaemias Secondary to Alteration in} Environment of Red Cells

Into this category may be brought together the haemolytic anaemias secondary to certain infections, splenic hyperplasia, vascular disease, disseminated carcinoma, and Hodgkin's disease.

\section{Infections}

The anaemia of acute or chronic infections is not well understood; there is probably not only an element of impaired erythropoiesis but also often increased haemolysis of varying severity. The possibility of an immune mechanism leading to acute haemolysis has already been mentioned. In other cases a lesser intensity of haemolysis may be the consequence of splenic hyperplasia !eading to an abnormal degree of red-cell sequestration (Jandl, Jacob, and Daland, 1961). It seems likely that the haemolytic anaemia of so-called hypersplenism is brought about in a similar way. An additional factor in some instances - for example, in Clostridium welchii infection-is that, by chemical action, the bacterial toxin damages the red cells directly (Isham and Finch, 1956).

\section{Vascular Disease: Microangiopathic Haemolytic Anaemia}

Recently it has been recognized that an interesting and characteristic type of haemolytic anaemia develops in association with disorders characterized by disease of small blood-vessels (Brain. Dacie, and Hourihane, 1962). This is " microangiopathic haemolytic anaemia." It is found in its most severe and characteristic form in thrombotic thrombocytopenic purpura, where vascular disease is often widespread; but similar blood pictures may be met with in some cases of renal cortical necrosis, glomerulonephritis, and malignant hypertension. Haemolysis occurs to some extent in the blood-stream and there may be haemoglobinuria; many mature red cells can be seen to be contracted and distorted-the most abnormal have been described as triangular, helmet, or burr cells-and there may be evidence of actual red-cell fragmentation.

This blood picture is not associated with uraemia per se, although many patients whose blood undergoes these changes are in fact uraemic ; but they need not be. A common feature of these patients is, however, the presence of disease of small blood-vessels, and it seens likely, or at least possible, that the haemolysis is due in some way to reprated contact between the red cells and the inflamed and pathologically altered small bloodvessels. Whether the damage to the red cells is due to ehemical contact or the mechanical trauma sustained by the cells being forced through damaged and partially blocked vascular "channels is uncertain.

Similar blood pictures are found in some patients suffering from disseminated carcinoma. In these cases, too, lesions of small blood-vessels or intravasal carcinoma have been found. It is possible here, too, that it is contact between the red cells and diseased vessel walls or tumour tissue which damages the red cells.

An interesting haemolytic anaemia is found in association with disseminated lymphadenoma. This, too, may have a complicated origin, but one interesting morbid anatomical finding is the surrounding of tumour nodules in the spleen with a cuff of iron-laden phagocytes. Again, it seems possible that it is contact between red cells and growing lymphadenomatous tissue or metabolites derived from the tumour that brings about haemo!ysis -locally.

\section{"Traumatic" (Mechanical) Haemolytic Anaemia}

That contact with abnormal tissue mav bring about a serious degree of intravascular haemoiysis has been emphasized by the occurrence of a small number of cases of haemolytic anaemia following reconstructive cardiac surgery. One such case has recently been described by Sayed, Dacie, Handley, Lewis, and Cleland (1961). This patient, studied at the Postgraduate Medical School of London, had a large septum primum defect in his heart which was repaired by a graft of the synthetic material "teflon." Subsequently, severe intravascular haemolysis developed, with continuous haemoglobinuria. 
The patient was known to have a cleft in the mitral valve, and it seemed likely that a regurgitant jet of blood was playing on the teflon sepium and that this was preventing the teflon from being covered by endothelium, and that the regurgitating blood was undergoing a significant amount of traumatic haemolysis. The appearances of peripheral blood films in which distorted and fragmenting red cells were continuously visible supported this hypothesis.

After six months of waiting, during which time many transfusions had to be given, the patient's heart was re-explored. The local situation was much as predicted; there was a small cul-de-sac in the septum at the base of which was bare teflon which felt to the touch like sandpaper. The cul-de-sac was closed by having its edge; sewn together and the teflon was covered up. Haemolysis ceased immediately (see Chart).

March haemoglobinuria also seems likely to be a haemolytic anaemia of traumatic origin, but where in the body the haemolysis takes place and exactly why and how are unknown. It is known, however, that haemolysis occurs only if exercise is taken in the upright lordotic posture, not when the back is bent (Gilligan and Blumgart, 1941). In view of this, it is perhaps justifiable to wonder whether kinking of blood-vessels causing an abrupt change in the direction of the blcod flow when the back is hyperextended, in association with a rapid circulation rate, might result in sufficient traumatic destruction of the red cells to produce overt haemoglobinaemia and haemoglobinuria.

Haemolytic Anaemias Secondary to Drugs

This is a very large subject which it is impossible to deal with in any detail.
As already mentioned, an explanation for the abnormal incidence of haemolytic drug reactions in negroes and certain other racial groups, such as Sephardic Jews, has been found in the relatively high incidence of deficiency in their red cells of glucose-6phosphate dehydrogenase. This is certainiy a much commoner mechanism of haemolysis than the autoimmune mechanism which also has been briefly referred to, in which a racial predisposition is not an important factor. But, aside from these manifestations of idiosyncrasy or hypersensitivity, certain drugs regularly damage red cells if taken in sufficient dosage.

The way these drugs act is probably diverse. But the net result is varying degrees of contraction and distortion of the red cells, spherocytosis, Heinz-body formation, and sometimes punctate basophilia-all signs of severe damage to the cell surface and the haemoglobin it contains. Haemolysis occurs in the blood-stream in fulminating cases, and the damaged red cells are probably also removed from the circulation by phagocytic cells widely throughout the body.

\section{CONCLUSION}

I have attempted in this brief survey to describe some of the more interesting developments in the knowledge of the factors which limit the life of the red cell in health and shorten its life-span in disease. It is interesting to reflect on the multitude of mechanisms which can lead to an increased rate of haemolysis, and whether there are any other cells in the body which can fail to function in so many different ways. It is also interesting to note that all the various hypothetical
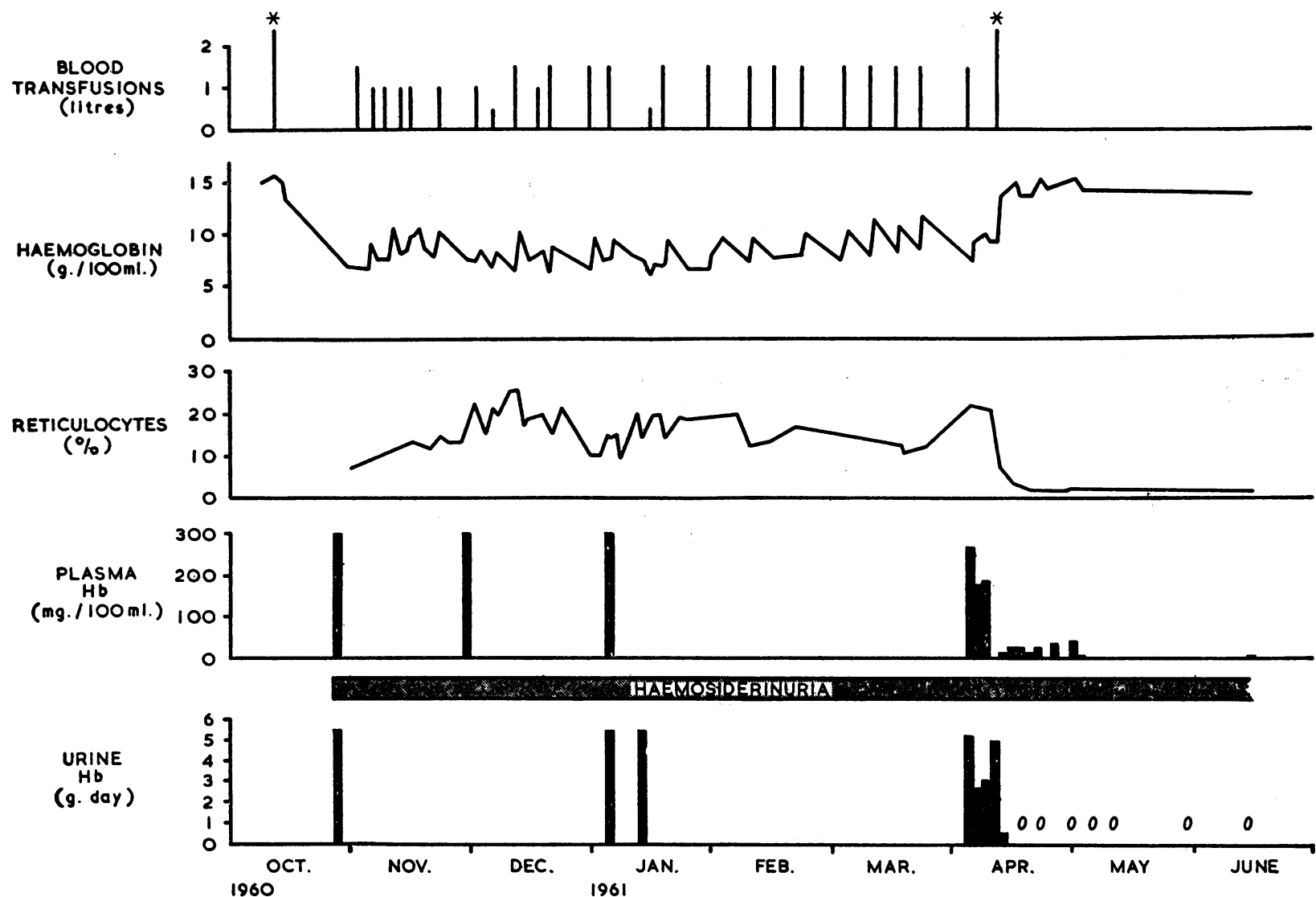

Clinical course and haematological findings of the patients described by Sayed et al. (1961). The times of the two cardiac operations are indicated by the asterisks. (Reproduced by permission of the Editor of Thorax.) 
mechanisms which have been thought at one time or another to limit the life-span of the red cell in healthmetabolic failure, removal from the circulation by phagocytic cells, the action of the spleen, fragmentation in the circulation, actual lysis in the circulation-have all been shown to be important factors under the abnormal circumstances which we call disease.

\section{References}

Aliison, A. C., and Burn, G. P. (1955). Brit. J. Haemat. 1,291 .

Altman. K. I., Tabechian, H., and Young, L. E. (1958). Ann. N.Y. Acad. Sci., 75, 142 .

Auditore, J. V., and Hartman, R. C. (1959). Amer. J. Med., 27, 401.

Belcher, E. H., and Harriss, E. B. (1959). J. Physiol. (Lond.), 146, 217.

Bernstein, R. E. (1959). J. clin. Invest., 38, 1572

Beut'er, E. (1959). Blood, 14, 103

Bonnin. J. A., and Schwartz. L. (1954). Ibid., 9. 773.

Borun. E. R., Figueroa, W. G., and Perry, S. M. (1957). J. clin. Invest.. 36, 676

Erain, M. C., Dacie, J. V., and Hourihane, D. O'B. (1962). Brit. J. Haemat.. 8. In press.

Braunsteiner, H., Gisinger, E., and Pakesch, F. (1956). Blood. 11. 753 .

Cecchi, E., and Conestabile, E. (1957). Lancet, 2. 466.

Cherikow, G., and Dacie, J. V. (1956). Brit. J. Hiemat. 2. 237.

Dacie. J. V. (1954a). The Haemolytic Anaemias: Congenital and Acquired, p. 423. Churchill, London.

(1954b). Ibid., p. 331

- (1960). Ibid. 2nd ed.. p. 195. Churchill, London.

- (1962a). Ibid., 2nd ed., p. 406

(1962b). Proc, roy Soc. Med. 55, 28

- and Lewis, S.M (1961) Brit, J Haemat 7442

Danon. D.. and Marikovsky, Y. (1961). C.R. Soc. Biol. (Paris) 155, 12 .

Dameshek, W., and Schwartz, R. (1959). Ann. N.Y. Acad. Sci. 77. 589

de Gruchy, G. C. (1960). Aust. Ann. Med. 9. 237.

Loder, P. B., and Hennessy, I. V. (1962). Brit. J. Haemat. 8. 168 .

De Sandre, G., Ghiotto, G., and Mastella, G. (1956). Acta med. Hist. p:tal., 16, 310 .

Gilligan, D. R., and Blumgart, H. L. (1941). Medicine (Baltimore), 20, 341 .

Grimes, A. J., and Meisler, A. I. (1962). Nature (Lond.), 194 190

Harris, J. W. (1954). J. Lab. clin. Med., 44, 809.

Hinz, C. F., jun.. Jordan, W. S., jun., and Pillemer, L. (1956). J. clin. Invest., 35. 453.

Hughes Jones, N. C. (1961). Clin. Sci.. 20, 315

- and Cheney, B. (1961). Ibid. 20, 323

Hunter, W. (1901). Pernicious Anaemia: Its Pathology. Septic Origin, Sympioms, Diagnosis, and Treatment. p. 363 Griffin, London.

Isaacs, R. (1937). Physiol. Rev.. 17. 291.

Isham, R. L., and Finch, S. C. (1956). New Engl. J. Med., 254 317.

Isliker, H. (1959). Immunopathology: Ist International Symposium. p. 29, edited by P. Graber and P. Miescher. Schwate, Basel.

Jandl, J. H. (1960). Proc. 7th int. Congr. int. Soc. Hematol. Rome, Sept. 7-13, 1958, p. 45. Il Pensiero Scientifico, Roma. (1961). Kernicterus, p. 41. edited by A. Sass-Kortsák. Toronto University Press, Oxford. University Press, London. Jacob, H. S., and Daland, G. A. (1961). New Engl. J. Med., 264. 1063

and Kaplan, M. E. (1960). J. clin. Invest. 39, 1145.

Jones, A. R., and Castle, W. B. (1957). Ibid.. 36, 1428

K Simmons, R. L.. and Castle. W. B. (1961). Blood. 18, 133

Kates, M., Allison, A. C., and James, A. T. (1961). Biochim. biophys. Acta (Amst.), 48. 571 .

Kirkman, H. N., and Riley, H. D., jun. (1961). Amer. J. Dis. Child.. 102., 313 .

Lewis. S. M. (1962). Brit. J. Hammat. In press.

- Dacie, J. V., and Tills, D. (1961). Ibid., 7, 64

- Szur, L., and Dacie, J. V. (1960). Ibid., 6, 122

Löhr, G., Waller, H. D.. Karges. O.. Schlegel, B., and Müller A. A. (1958), Klin. Wschr.. 36, 1008 .

London, I. M. (1960). Bull. N.Y. Acad. Med., 36, 79

Marks, P. A. (1961). Nouv. Rev. franc. Hémat.. 1 900

- and Johnson, A. B. (1958), J. clin. Invest, 37, 1542

Hirschberg, E., and Banks, J. (1958). Ann. N.Y Acad. Sci.. 75, 95

Matthes, M, Schubothe, H., and Lindemann, B. (1951). Acta haomat.'(Basel). $5,193$.

Metz. J., Rradlow, B. A., Lewis, S. M., and Dacie, J. V. (1960). Brit. J. Hiemit. 6,372

Miescher, P. (1956). Rev. Hémat. 11, 248

Mollison, P. L. (195\%). Erit. med. J., 2, 1035, 1123.
Prankerd, T. A. J. (1958). J. Physiol. (Lond.), 143, 325.

(1959). Brit. med. Bull. 15, 54

(1960). Qucrt. J. Med., 29, 199.

(1961). The Red Cell: An Account of its Chemical Physio logy and Pathology, p. 123. Blackwell, Oxford.

Altman, K. I., and Young, L. E. (1955). J. clin. Invest. 34. 1268 .

Reed, C. F., and Swisher, S. N. (1960). J. clin. Invest., 3), 1019.

Rigas, D. A., and Koler, R. D. (1961). Blood, 18, i.

Robinson, M. A., Loder. P. B., and de Gruchy, G. C. (1961) Brit. J. Haemat., 7, 327.

Rous, P. (1923). Physiol. Rel., 3, 75

- and Robertson, O. H. (1917). J. exp. Med., 25. 65I

Sayed, H. N., Dacie, J. V., Handiey, D. A., Lewis, S. M., and Cleland, W. P. (1961). Thorax, 16, 356 .

Schmid, R. (1961). Nouv. Rev. franc. Hémat., 1, 801.

Selwyn, J. G., and Dacie, J. V. (1954). Blood, 9, 414.

Shahidi, N. T., and Diamond, L. K. (1959). Pediatrics, 24, 245

Simon, E. R., and Topper, Y. J. (1957). Nature (Lond.), 180 1211.

Singer, K., and Weisz, L. (1945). Amer. J. med. Sci.. 210, 301

Smith. E. W., and Krevans, J. R. (1959). Bull. Johns Hoph Hosp.. 104, 17

Stewart, W. B., Stewart, J. M., Izzo, M. J., and Young, L. E. (1950). J. exp. Med.. 91, 147.

Tabechian, H.. Altman, K. I., and Young, L. E. (1956). Proc. Soc. exp. Biol. (N.Y.) 92,712

Teitel-Bernard, A. (1930). C.R. Soc. Biol. (Paris), 103, 829

Valentine, W. N., Tanaka, K. R., and Miwa, S. (1961). Trans. Ass. Amer. Phycns. 74, 100.

Weiss, L. (1957). J. biophys. biochem. Cytol., 3, 599.

\section{CONGENITAL TEMPORARY DIABETES MELLITUS}

BY

\section{JAMES H. HUTCHISON, M.D., F.R.C.P.} F.R.C.P.Ed., F.R.F.P.S.

Samson Gemmell Professor of Child Health. University of Glasgow

A. J. KEAY, M.B., M.R.C.P.Ed., D.C.H.

Consultant Paediatrician. Northern Group of Hospitals, Edinhurgh

AND

MARGARET M. KERR, M.D., D.C.H.

Assistant Paediatrician, Glasgow Royal Maternity and Women's Hospital

The literature of diabetes mellitus in infancy reveals a certain amount of confusion, largely attributable to the fact that the aetiology of diabetes remains unknown. It is well recognized that in adults the term diabetes mellitus inchudes more than one disease. It is perhaps insufficiently appreciated that the same is true of the infant. Two types can now be separated. In older infants insulin-sensitive diabetes mellitus with ketosis and acidosis necessitates the lifelong use of insulin, and it is not distinguishable from the common type of diabetes of later childhood and early adult life. There is, however, another type, with onset at or shortly after birth, which is also insulin-sensitive but is not accompanied by ketosis, and which appears to be capable of spontaneous recovery. The first such case was described by Kitselle in 1852 in his own newborn son, who died after a short period of polyuria, polydipsia, glycosuria, and emaciation. Once recognized, this disease has a rather characteristic clinical picture. We now report four cases in the hope that recognition of other cases will be encouraged. There is reason to believe that a lack of awareness has led to mistaken diagnoses and the preventable deaths of some affected infants. Case 1 was previously reported by Wylie (1953) before it was appreciated that spontaneous recovery from the diabetes. could occur. 